ISSN 0258-7122 (Print), 2408-8293 (Online)

Bangladesh J. Agril. Res. 44(4): 621-630, December 2019

\title{
INCIDENCE OF MAJOR INSECT PESTS ON SWEET GOURD GERMPLASM
}

\author{
M. AFroz 1 , M. R. AMIN ${ }^{2}$, M. R. U. MIAH ${ }^{3}$ AND M. M. HOSSAIN ${ }^{4}$
}

\begin{abstract}
Abundance of the major insect pests viz., red pumpkin beetle, epilachna beetle and fruit fly on twelve sweet gourd germplasms namely BD 264, BD 265, BD 266, BD 268, BD 269, BD 274, BD 275, BD 277, BARI Mistikumra 1, BARI Mistikumra 2, Gazipur Local Line and China line was studied in the experimental field of the Department of Entomology, Bangabandhu Sheikh Mujibur Rahman Agricultural University, Gazipur, Bangladesh during July 2018 to June 2019. The mean number of red pumpkin was the highest ( 2.3 adults/ 3 leaves) during $4^{\text {th }}$ week of December and the lowest ( 0.7 adults/ 3 leaves $)$ during $4^{\text {th }}$ week of March. The mean number of grub ( 6.5 grubs/3 leaves) and adult $(2.3$ adults/ 3 leaves) of epilachna beetle were the highest during $2^{\text {nd }}$ week of March and $4^{\text {th }}$ week of February, respectively. The mean number of fruit fly was found the lowest $\left(1.0\right.$ adults plant $\left.{ }^{-1}\right)$ during $5^{\text {th }}$ week of January and the highest $(2.5$ adults plant ${ }^{-1}$ ) during $4^{\text {th }}$ week of February. BARI Mistikumra 1, BARI Mistikumra 2 and China Line provided the lowest yield ranged from $4.8 \pm 5.3$ to $7.4 \pm 0.5 \mathrm{t} \mathrm{ha}^{-1}$ and the remaining germplasms showed statistically similar yield.
\end{abstract}

Keywords: Cucurbita moschata, germplasms, red pumpkin beetle, epilachna beetle, fruit fly.

\section{Introduction}

Sweet gourd, Cucurbita moschata Duch, a nutritive vegetable belongs to the family Cucurbitaceae grows in Bangladesh and around the world. Cucurbitaceae is one of the largest families having 118 genera and 825 species (Rai and Kumar, 2008). In Bangladesh, a total of 28.5 thousand hectares of land were occupied for sweet gourd cultivation with an annual production of 294.5 thousand tons in the year of 2016-17, and the average yield of sweet gourd was $9.22 \mathrm{t} \mathrm{ha}^{-1}$ and $11.0 \mathrm{t}$ $\mathrm{ha}^{-1}$ in summer and winter, respectively (BBS, 2017).

The red pumpkin beetle, epilachna beetle, cucurbit fruit fly, thrips, cutworm, aphid and whitefly are the major constraints of cucurbit production due to their constant attacks which lead to severe yield loss. Among the harmful insects, red pumpkin beetle Aulacophora foveicollis Lucas (Coleoptera: Chrysomelidae), epilachna beetle Epilachna dodecatigma Wied., E. vigintioctopunctata Fab. (Coleoptera: Coccinellidae) and cucurbit fruit fly Bactrocera cucurbitae

\footnotetext{
1,2,3 Department of Entomology, Bangabandhu Sheikh Mujibur Rahman Agricultural University (BSMRAU), Gazipur, ${ }^{4}$ Department of Horticulture, BSMRAU, Gazipur, Bangladesh.
} 
Coquillett, B. dorsalis Hendel (Diptera: Tephritidae) showed higher abundance and caused serious damage on sweet gourd (Ali et al., 2015; Nancy et al., 2018).

Red pumpkin beetle attacks young plants, leaves and flowers and feed on both surface of leaves and produce a characteristic, circular ring like injury and cause 30 to $100 \%$ yield loss (Aslam et al., 2017). Both adult and grub of epilachna beetle infest throughout the growth stages of crop and the grubs scrap the epidermis while the adults make semicircular cuts in rows on the epidermis of leaves thus cause up to $80 \%$ infestation of the host plant (Ghule et al., 2014). Female fruit fly deposits eggs below the skin of the fruit and the maggots developed inside the fruit feed on the inner pulp and they cause up to $71.5 \%$ fruit infestation on sweet gourd in Bangladesh (Amin et al., 2011a).

Seasonal variations of the weather factors play a vital role in multiplication, growth, development and distribution of insects, and influence on their population dynamics (Namni et al., 2017). Fruit flies showed fluctuations in their abundance on sweet gourd and caused higher infestation in summer than winter (Amin et al., 2019). Plant species and their varieties, cultivars and germplasms varied in their morphological traits and biochemical contents and affect the growth, development, reproduction and abundance herbivore insects (Amin et al., 2011b; Amin et al., 2015a; Amin et al., 2017).

Information on population fluctuations and infestation of the major insect pests is important in forecasting and warning system and to find out resistant germplasm through screening is very useful in pest management program. With this point in view, the study was conducted to know the abundance of red pumpkin beetle, epilachna beetle and fruit fly on twelve germplasms of sweet gourd.

\section{Materials and Methods}

\section{Study site and condition}

The study was conducted during July 2018 to June 2019in the field and laboratory of the Department of Entomology, Bangabandhu Sheikh Mujibur Rahman Agricultural University (BSMRAU), Gazipur, Bangladesh. The site is located at $25^{\circ} 25^{\prime}$ North latitude and $89^{\circ} 5^{\prime}$ East longitude having annual mean maximum and minimum temperatures, relative humidity and rainfall 36.0 and $12.7^{\circ} \mathrm{C}, 65.8 \%$ and $237.6 \mathrm{~cm}$, respectively (Amin et al., 2015b).

\section{Experimental materials and raising of seedling}

Twelve sweet gourd germplasm, namely BARI Mistikumra-1, BARI Mistikumra-2, BD 264, BD 265, BD 266, BD 268, BD 269, BD 274, BD 275, BD 277, Gazipur Local Line and China Line were used in this study. The seeds were collected from Bangladesh Agricultural Research Institute, local market of Gazipur and Department of Entomology, BSMRAU, and the seeds were sown in polybags on 14 November to raise seedling. 


\section{Experimental design and cultivation of the germplasms}

The germplasms were cultivated in $4.0 \mathrm{~m} \times 3.0 \mathrm{~m}$ plots following randomized complete block design with three replications. The spacing between block to block and plot to plot was $1.0 \mathrm{~m}$ and $1.0 \mathrm{~m}$, respectively. Three weeks aged seedlings were transplanted to the field on December 4, 2018. All the intercultural operations except insect pest management were done whenever necessary and fertilizers were applied according to Fertilizer Recommendation Guide (FRG, 2018).

\section{Observation of plant growth and morphological traits}

Weekly observations were done to collect data on initiation of branch, flower and fruit, fruit elongation, maturity of fruit for market and seed production.

\section{Observation of insect abundance}

Systemic sampling at weekly interval was employed to collect data on the abundance of red pumpkin beetle, epilachna beetle and fruit fly. Five plants for each germplasm were selected and the abundance (number/ 3 leaves) of adult red pumpkin beetle, and grub and adult epilachna beetle on top, middle and bottom leaves of a plant was noted. The number of adult fly sitting on the fruits of a plant was considered to know its abundance and the observations were replicated for five times.

\section{Quantifying yield}

The mature fruits of each plot were harvested and weighed using a digital balance (CANRY, China) and the data were converted to ton $\mathrm{ha}^{-1}$.

\section{Data analysis}

One way analysis of variance (ANOVA) followed by Tukey's HSD posthoc test was employed for analyzing the data. All the analyses were performed using IBM SPSS 21.0.

\section{Results and Discussion}

The abundance of adult red pumpkin beetle on sweet gourd germplasms showed fluctuations throughout the study period (Figure 1). The incidence of red pumpkin beetle was found from $2^{\text {nd }}$ week of December to $4^{\text {th }}$ week of March. Red pumpkin beetle population showed a sudden decrease in $3^{\text {rd }}$ week of December having the mean abundance 1.0 adult/ 3 leaves. This might happen due to sudden winter rainfall during that period. Khan et al. (2015) found that rainfall had negative impact on red pumpkin beetle population. Red pumpkin beetle population sharply increased and reached to the peak with mean abundance 2.3 adults $/ 3$ leaves during $4^{\text {th }}$ week of December. This finding was different from that 
of Khan et al. (2015) who found the peak abundance of red pumpkin beetle during February to April. The variation might happen due to the variation of crop growing period. They conducted the experiment during summer whereas the present study was conducted during winter. With the advent of plant growth, the population of beetle declined. As the beetles prefer young plants, their population was the maximum during early growing season. Shrikrushna (2012) reported that the adult and grub of the insect caused the most serious damage to seedlings due to their attractive greenness and palatability. During the next few months, red pumpkin beetle showed a little change in its population. The beetle population increased slightly with mean abundance 1.4 adults/3 leaves during $2^{\text {nd }}$ week of March and finally decreased at the very end of growing season during $4^{\text {th }}$ week of March (0.7 adult/3 leaves).

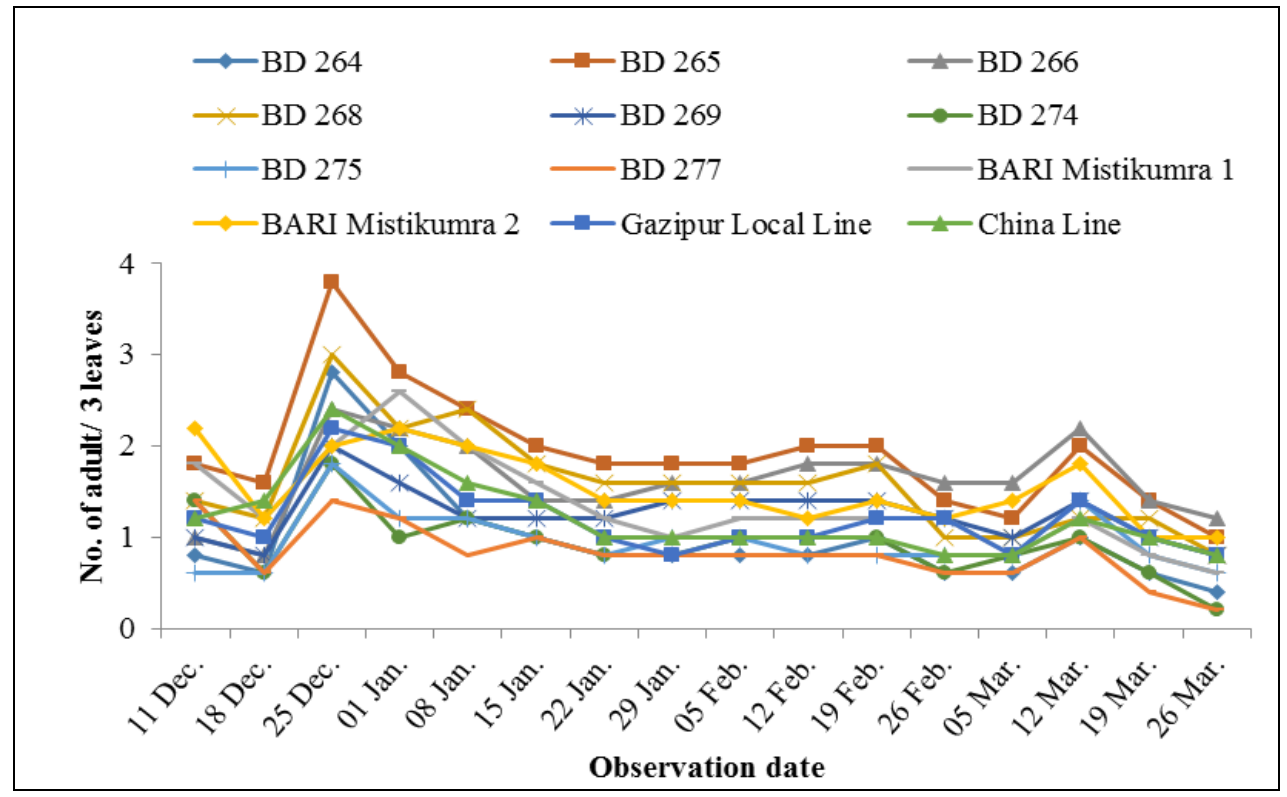

Fig. 1. Abundance of red pumpkin beetle on twelve sweet gourd germplasm during December 2018 to March 2019.

In the present study, the grub of epilachna beetle was first observed during $2^{\text {nd }}$ week of January and was persistent until harvesting of the crop (Figure 2). The presence of grub was more or less constant throughout the growing period and the lowest abundance of grub was recorded in $2^{\text {nd }}$ week of January with mean abundance 2.5 grubs/ 3 leaves. The population of grub reached its peak (6.5 grubs/3 leaves) in $2^{\text {nd }}$ week of March. Ghule et al. (2014) found that the population of epilachna beetle remained active during March to May. Uikey et al. (2016) observed that the population of epilachna beetle on bottle gourd remained active during the warmer part of the crop growing season and found a maximum of 8.4 grubs plant $^{-1}$ during the $4^{\text {th }}$ week of March. 


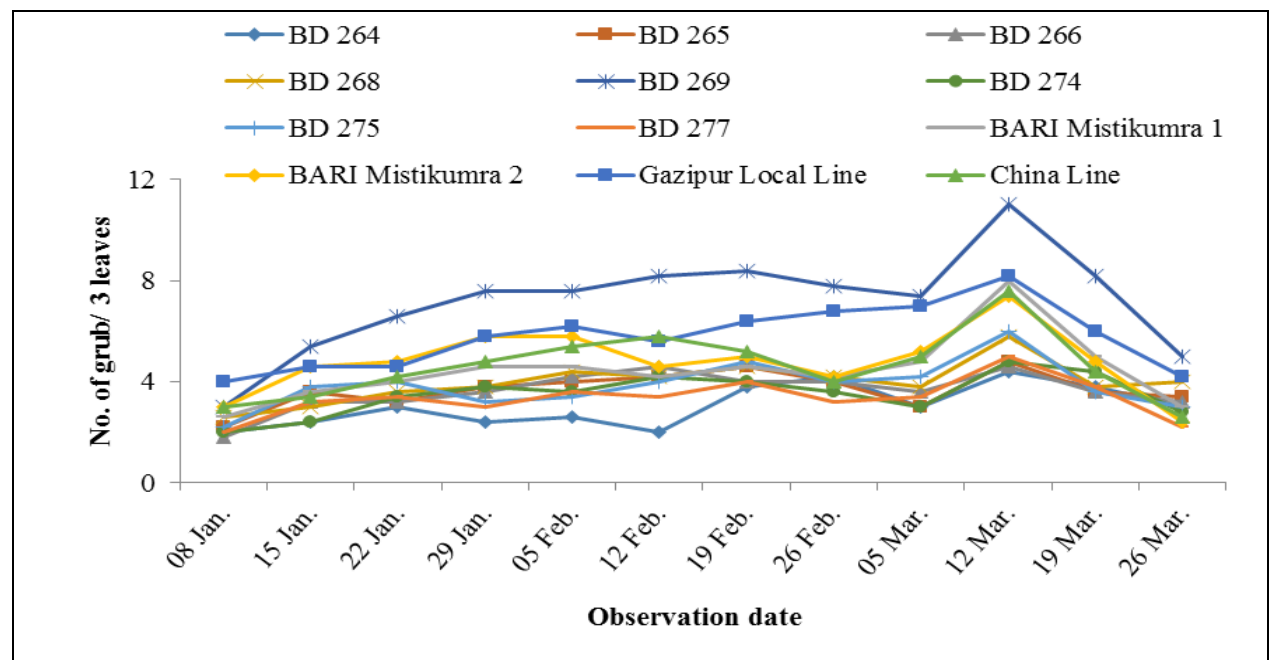

Fig. 2. Abundance of grubs of epilachna beetle on twelve sweet gourd germplasm during December 2018 to March 2019.

The adult epilachna beetle was first observed in $2^{\text {nd }}$ week of January and was continuously present till $4^{\text {th }}$ week of March (Figure 3 ). The mean abundance of the adult was the lowest (1.4 adults/ 3 leaves) during $1^{\text {st }}$ week of February. Then the number of adult epilachna beetle showed an increasing trend and reached the peak during $4^{\text {th }}$ week of February with the mean abundance 2.3 adults $/ 3$ leaves. After that, the abundance was gradually decreasing till $4^{\text {th }}$ week of March, the period of final harvesting. Bhowmik and Saha (2017) reported epilachna beetle as a serious pest of bottle gourd found its infestation from early September.

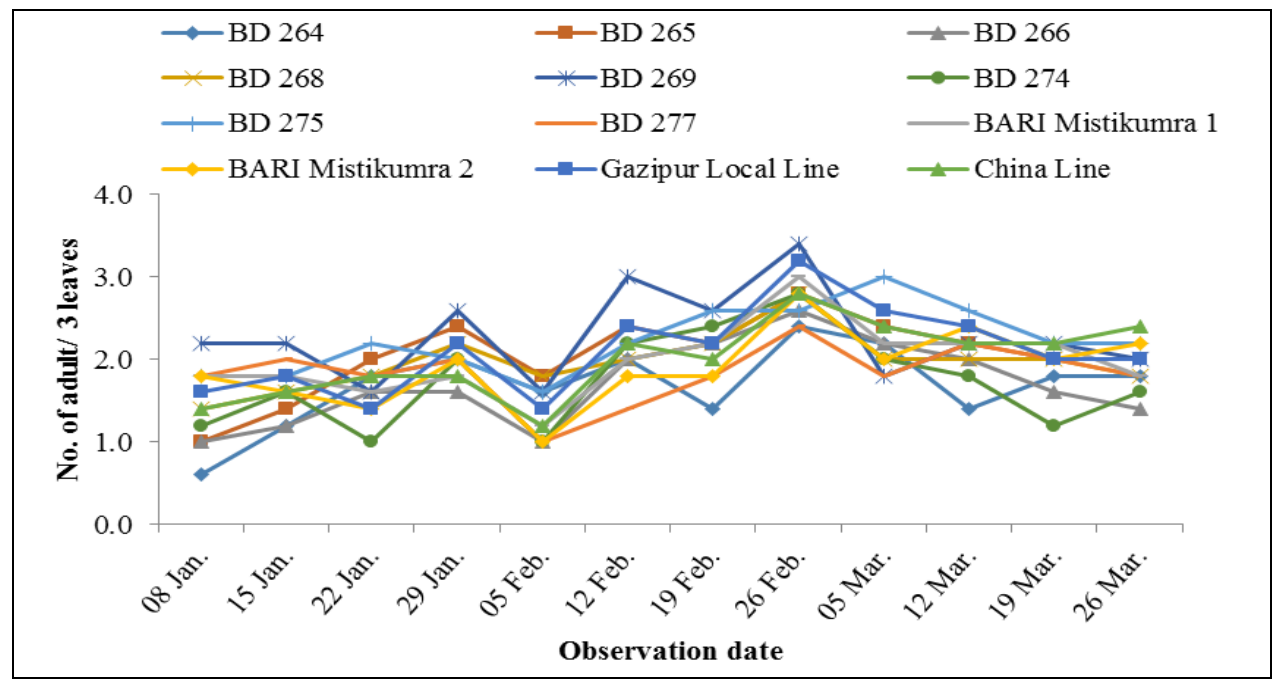

Fig. 3. Abundance of adult epilachna beetle on twelve sweet gourd germplasm during December 2018 to March 2019. 
The population of adult fruit fly started to appear in $5^{\text {th }}$ week of January which coincided with the period of fruit initiation and remained in the field till harvesting (Figure 4). The lowest mean number of fruit fly $\left(1.0\right.$ plant $\left.^{-1}\right)$ was found during $5^{\text {th }}$ week of January. The peak abundance of adult fruit fly was recorded during $4^{\text {th }}$ week of February with mean abundance 2.5 plant $^{-1}$. Then the population declined and a little number of fruit flies was recorded at the end of growing season. The present finding showed agreement with Amin et al. (2019) who reported that the B. cucurbitae increased in their abundance from the second week of January, increasing before reaching peak abundance in the fourth week of February.

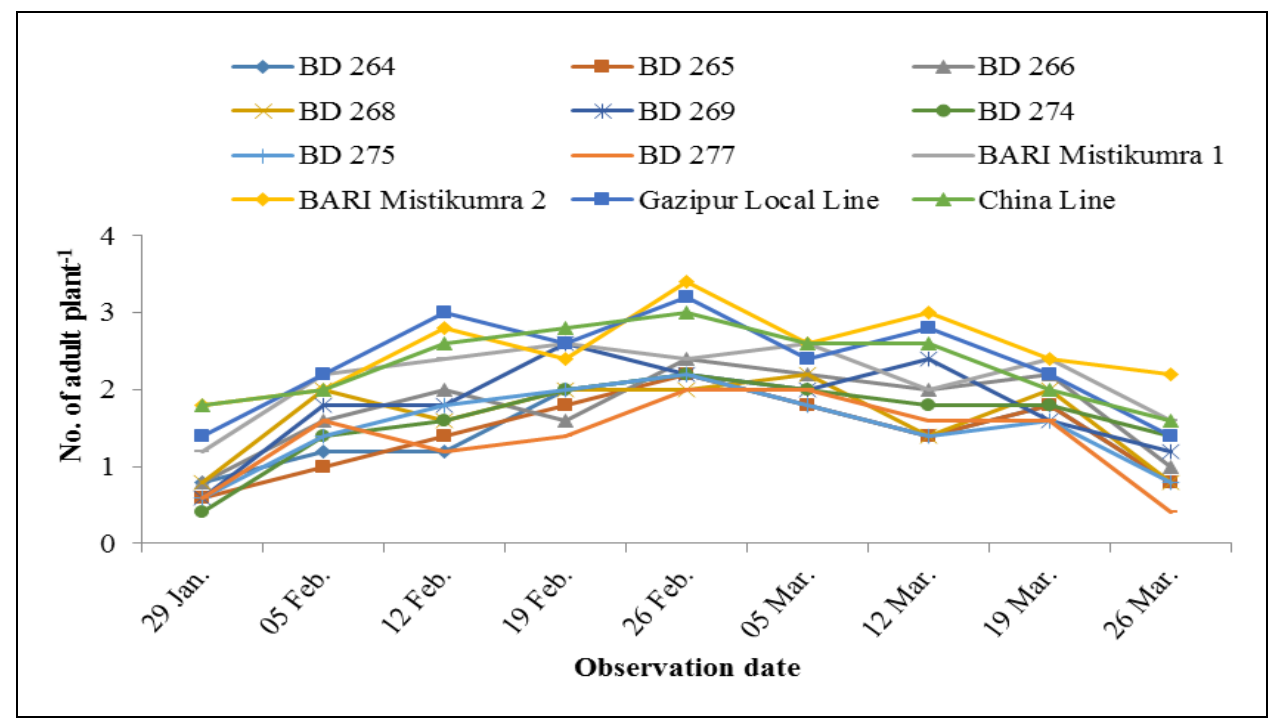

Fig. 4. Abundance of adult fruit fly on twelve sweet gourd germplasm during December 2018 to March 2019.

Different germplasms of sweet gourd vary in their durations of growth and development. The study revealed that there was significant variation in the durations of different developmental phenomena such as branch initiation $\left(\mathrm{F}_{11,48}\right.$ $=5.3, \mathrm{p}<0.001)$, flower initiation $\left(\mathrm{F}_{11,48}=10.5, \mathrm{p}<0.001\right)$, fruit initiation $\left(\mathrm{F}_{11,48}\right.$ $=3.2, \mathrm{p}<0.01)$, fruit elongation $\left(\mathrm{F}_{11,48}=2.8, \mathrm{p}<0.01\right)$, marketable maturity of fruit $\left(\mathrm{F}_{11,48}=5.3, \mathrm{p}<0.001\right)$ and seed production maturity of fruit $\left(\mathrm{F}_{11,48}=3.4, \mathrm{p}\right.$ $<0.01$ ) among twelve sweet gourd germplasms (Table 1). Results showed that the duration of branch initiation was the highest and statistically similar in BD 264, BD 274 and BARI Mistikumra 1 having mean duration $26.8 \pm 1.1,26.8 \pm$ 0.8 and $26.6 \pm 0.7$ days after transplanting (DAT), respectively. BD 266 took the shortest period for initiating branch with mean duration $20.2 \pm 0.4$ DAT. In case of flower initiation, Gazipur Local Line took the highest time $(46.0 \pm 0.7$ DAT). BD 274 and BD 275 showed statistically similar results and took the lowest 


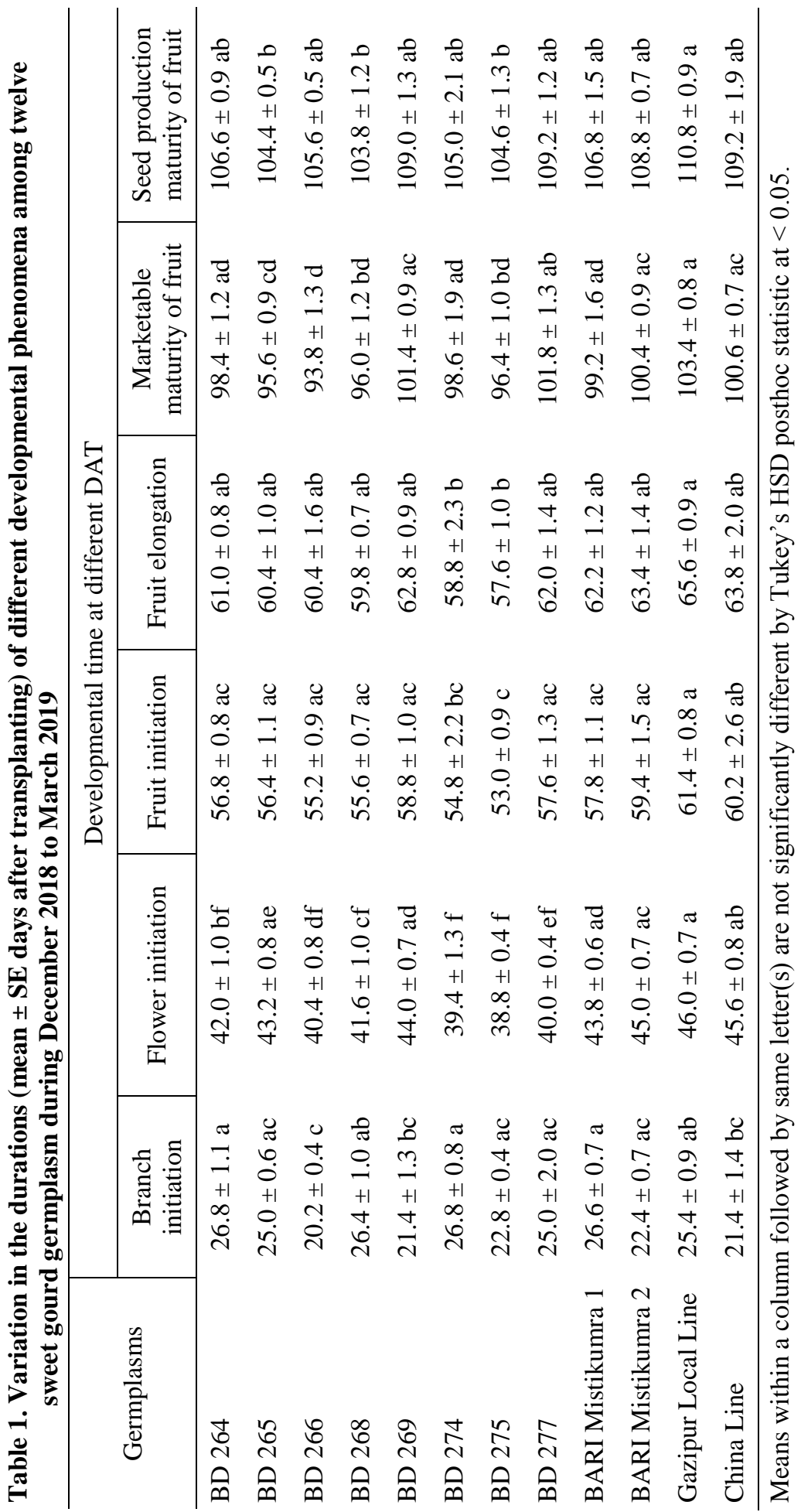


period for flower initiation $(39.4 \pm 1.3$ and $38.8 \pm 0.4$ DAT, respectively). Gazipur Local Line took the highest duration and BD 275 took the shortest duration for fruit initiation $(61.4 \pm 0.8$ and $53.0 \pm 0.9$ DAT, respectively). Gazipur Local Line took the maximum period for fruit elongation $(65.6 \pm 0.9$ DAT). BD 274 and BD 275 had identical as well as lower duration for fruit elongation $(58.8 \pm 2.3$ and $57.6 \pm 1.0$ DAT, respectively). Gazipur Local Line took the maximum period for attaining the fruit of marketable maturity and seed production maturity $(103.4 \pm 0.8$ and $110.8 \pm 0.9$ DAT, respectively). BD 266 showed the shortest duration for producing marketable matured fruit $(93.8 \pm 1.3$ days). BD 265, BD 268 and BD 275 had the minimum duration for attaining marketable maturity and seed production maturity of fruit $(104.4 \pm 0.5,103.8 \pm$ 1.2 and $104.6 \pm 1.3$ DAT, respectively). So, the total developmental period of tested germplasms during the study ranged from $103.8 \pm 1.2$ to $110.8 \pm 0.9$ DAT. The results were in accordance with the findings of Ahamed et al. (2011) who reported that genotypes of sweet gourd took 104 to 123 days for total development.

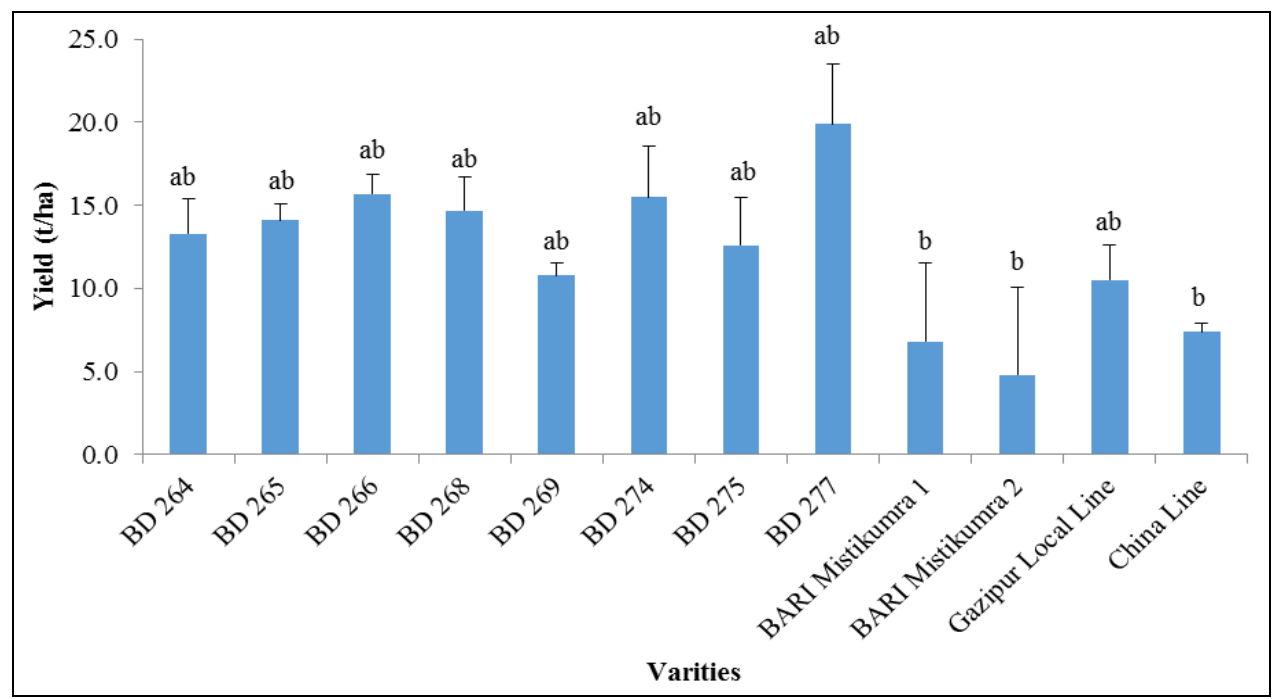

Fig. 5. Comparison of yield (mean $\pm \mathrm{SE}$ ) among twelve sweet gourd germplasm.

The yield of the tested germplasms is presented in figure 5. The yield of BD 264, BD 265, BD 266, BD 268, BD 269, BD 274, BD 275, BD 277 and Gazipur Local Line was statistically similar and comparatively higher ranged from $10.5 \pm 2.1$ to $19.9 \pm 3.6 \mathrm{t} \mathrm{ha}^{-1}$. BARI Mistikumra 1, BARI Mistikumra 2 and China line had the lowest and statistically similar yield ranged from $4.8 \pm 5.3$ to $7.4 \pm 0.5 \mathrm{tha}^{-1}$.

The abundance of red pumpkin beetle, epilachna beetle and fruit fly on sweet gourd germplasms showed fluctuations during the study period. The insect infested plants showed a great variation in case of duration for development, morphological traits and yield. The results of this study provide information for 
forecasting regarding the incidence of the major insect pests of sweet gourd and find out variations among the germplasms that could be helpful to develop resistant variety.

\section{References}

Ahamed, K. U., B. Akhter, M. R. Islam, N. Ara and M. R. Humauan. 2011. An assessment of morphology and yield characteristics of pumpkin (Cucurbita moschata) genotypes in northern Bangladesh. Trop. Agril. Res. Ext. 14: 5-10.

Ali, M. A., M. S. Islam, M. N. I. Sarker and A. M. Bari. 2015. Study on biology of red pumpkin beetle in sweet gourd plants. Intl. J. Appl. Res. 2: 1-4.

Amin, M. R., D. A. Tithi and Y. J. Kwon. 2011b. Characteristics of three cotton varieties and their impact on feeding and growth of cotton armyworm. Ent. Res. 41: 151-156.

Amin, M. R., R. Afrin, M. Z. Alam, M. M. Hossain and Y. J. Kwon. 2017. Effect of leaf trichomes and meteorological parameters on population dynamics of aphid and jassid in cotton. Bangladesh J. Agril. Res. 42: 13-25.

Amin, M. R., S. Namni, M. R. U. Miah, M. G. Miah, M. Zakaria, S. J. Suh and Y. J. Kwon. 2015b. Insect inventories in a mango-based agroforestry area in Bangladesh: foraging behavior and performance of pollinators on fruit set. Ent. Res. 45: 217-224.

Amin, M. R., T. Sarkar and I. J Chun. 2011a. Comparison of host plants infestation level and life history of fruit fly (Bactrocera cucurbitae Coquillett) on cucurbitaceous crops. Hort. Environ. Biotech. 52: 541.

Amin, M. R., M. C. Roy, M. M. Rahman, M. G. Miah, Y. J. Kwon and S. J. Suh. 2015a. Foraging and growth responses of the cotton armyworm (Spodoptera litura) to the biophysical characteristics of five cotton varieties. Ent. Res. 45: 286-293.

Amin, M. R., N. P. Nancy, M. R. U. Miah, M. G. Miah, O. Kwon and S. J. Suh. 2019. Fluctuations in fruit fly abundance and infestation in sweet gourd fields in relation to varied meteorological factors. Ent. Res. 49: 223-228.

Aslam, M. R., K. Javed, H. Javed, T. Ahmad and A. K. Kassi. 2017. Varietal resistance of pumpkin (Cucurbita pepo L.) germplasms against red pumpkin beetle (Aulacophora foveicollis) L. in Pothwar region. J. Ent. Zool. Stud. 5: 7-12.

BBS. 2017. Yearbook of Agricultural Statistics. Bangladesh Bureau of Statistics. Statistics and Informatics Division (SID), Ministry of Planning, Government of the People's Republic of Bangladesh. pp. 250-300.

Bhowmik, S. and S. Saha. 2017. Study on the pest complex of bottle gourd in the gangetic plains of West Bengal. J. Ent. Zool. Stud. 5: 725-727.

FRG. 2018. Fertilizer Recommendation Guide. Bangladesh Agricultural Research Council, Farm Gate, Dhaka.

Ghule, T. M., L. L. Devi and S. Jha. 2014. Seasonal incidence of epilachna beetle (Henosepilachna septima Dieke) in relation to weather parameters on pointed gourd (Tricosanthes dioica Roxb.). J. Crop and Weed. 10: 430-432.

Khan, L., M. Shah and A. Usman. 2015. Host preference of red pumpkin beetle (Aulacophora faveicollis) Lucas (Chrysomelidae: Coleoptera) among different Cucurbits. J. Ent. Zool. Stud. 3: 100-104. 
Namni, S., M. R. Amin, M. R. U. Miah, M. F. Rahman and S. J. Suh. 2017. Role of weather parameters on seasonal abundance of insects in a mango-based agroforestry in Bangladesh, with particular reference to mango hopper. Bangladesh J. Agril. Res. 42: 197-205.

Nancy, N. P., M. R. Amin, M. R. U. Mia and M. G. Miah. 2018. Diversity of insects in sweet gourd field of Bangladesh. Indian J. Ecol. 45: 854-857.

Rai, M. P. S. and S. Kumar. 2008. Cucurbit research in India: A retrospect Cucurbitaceae. In: Cucurbitaceae Pitrat, M. (ed.). Proceedings of the IX Eucarpia Meeting on Genetics and Breeding of Cucurbitaceae, Inra, Avignon, France.

Shrikrushna, D. S. 2012. Studies on insect pest complex and screening of improved varieties of bottle gourd (Lagenaria siceraria). MS Thesis. Department of Entomology, Jawaharlal Nehru KrishiVishwaVidyalaya, Jabalpur.

Uikey, B. L., B. Kumar, T. M. Ghule, S. Jha and R. K, Kekti. 2016. Incidence pattern and biology of epilachna beetle (Henosepilachna septima Dieke) on bottle gourd in gangetic new alluvial zone of West Bengal. J. Insect Sci. 29: 63-66. 